\title{
Makna Sukses di Masa Lanjut
}

\author{
Funi Rahmawati, Satih Saidiyah \\ UIN Sunan Kalijaga, Jl. Marsda Adisucipto, Yogyakarta \\ e-mail: satihsaidiyah@yahoo.co.id
}

\begin{abstract}
Being a successful elderly is the purpose of the development stage of late elderly. The aim of study was to determine the meaning of success reflected by the elderly couple. This study used a phenomenology approach through data collection methods were interview and observation. The results showed that the meaning of success was when they have the benefit of the previous enterprises and it shared with children and grandchildren. On the other hand, success also means the happiness of the family when the family is harmonious. As a couple, they capable in maintain mutually support each other and solving problem together. The factors have affecting in elderly success namely physical healthy, activities, psychological factors, social factors, and religiosity.
\end{abstract}

Keywords: elderly, meaning of success, happiness

\begin{abstract}
Abstrak
Menjadi tua yang berhasil merupakan tujuan dari perkembangan tahap akhir lanjut usia. Penelitian ini bertujuan untuk mengetahui makna sukses di masa lanjut pada pasangan suami istri lanjut usia. Penelitian ini menggunakan pendekatan kualitatif-fenomenologi melalui metode pengumpulan data wawancara dan observasi. Hasil penelitian menunjukkan bahwa makna sukses pada pasangan suami istri lanjut usia adalah ketika dapat menikmati hasil usahanya serta dapat berbagi dengan anak dan cucu. Akan tetapi di sisi lain, sukses juga diartikan dengan kebahagiaan keluarga di mana subjek mempunyai keluarga yang rukun. Bahkan meskipun kini hanya tinggal berdua bersama pasangan, tetapi mereka saling mendukung satu sama lain dan ketika ada masalah pun berusaha untuk menyelesaikannya bersama. Faktor yang mempengaruhi kesuksesan di masa lanjut adalah faktor kesehatan fisik, faktor aktivitas, faktor psikologis, faktor sosial, dan faktor religiusitas. Kesamaan kedua pasangan lanjut usia dalam penelitian ini terletak pada usaha yang dilakukan untuk mencapai kesuksesan.
\end{abstract}

Kata Kunci: usia lanjut, makna sukses, kebahagiaan

\section{Pendahuluan}

Lanjut usia merupakan tahap terakhir dari rentang perkembangan manusia. Lanjut usia sering dimaknai sebagai masa kemunduran. Semakin panjang usia seseorang, sejalan dengan pertambahan usia tubuhnya maka akan semakin mengalami kemunduran fisik maupun psikologis. Secara fisik, seorang lanjut usia akan terlihat keriput pada kulit-kulitnya, rambut memutih dan menipis, fungsi panca indera berkurang, dan bahkan mudah terserang penyakit karena daya tahan tubuhnya mulai berkurang. Sedangkan secara psikologis, seorang lanjut usia mulai mengalami penurunan daya ingat, dibatasinya melakukan kegiatan-kegiatan baik di dalam maupun di luar rumah, mengalami kebosanan bahkan kesepian.

Lanjut usia disebut juga sebagai usia emas karena tidak semua orang dapat mencapai usia tersebut, maka lanjut usia memerlukan tindakan perawatan, baik yang bersifat promotif maupun preventif agar ia dapat menikmati masa usia emas serta menjadi lanjut usia yang berguna dan bahagia (Maryam, 2008). Suardiman (2011) menyatakan bahwa semua makhluk hidup memiliki siklus kehidupan menuju tua yang diawali dengan proses kelahiran, kemudian tumbuh menjadi dewasa, dan berkembangbiak, selanjutnya menjadi semakin tua dan akhirnya akan meninggal.

Pada saat ini jumlah lanjut usia di Indonesia diketahui terus meningkat. Berdasarkan data kependudukan dari Badan 
Pusat Statistik (BPS), jumlah penduduk lanjut usia yang berusia 60 tahun ke atas pada tahun 1971 berjumlah 5,31 juta jiwa (4,5\%), pada tahun 1996 mengalami peningkatan menjadi 13,30 juta jiwa (7,4\%), dan pada tahun 2020 diperkirakan jumlah lanjut usia akan menjadi 28,82 juta jiwa (11,3\%) (Suardiman, 2011). Meningkatnya jumlah lanjut usia tersebut tidak jauh dari faktor keberhasilan dalam meningkatkan kesehatan masyarakat yang ditandai dengan meningkatnya usia harapan hidup. Sedangkan struktur penduduk yang menua tersebut merupakan salah satu indikator keberhasilan pencapaian pembangunan nasional, khususnya sebagai cerminan dari semakin panjangnya rata-rata usia penduduk Indonesia.

Menurut data Bappenas, Daerah Istimewa Yogyakarta tercatat menjadi provinsi paling dini mengalami penuaan. Jumlah persentase orang yang berusia lebih dari 60 tahun, paling banyak dari semua provinsi (www.megapolitan.kompas.com, 2014). Naiknya jumlah lanjut usia adalah dampak meningkatnya Usia Harapan Hidup (UHH). Provinsi Daerah Istimewa Yogyakarta merupakan provinsi dengan harapan hidup penduduk tertinggi se-Indonesia. Hasil proyeksi dasar Sensus Penduduk (SP) pada 2010, UHH di Yogyakarta 74,2 tahun. Sementara itu, pada 2035 nanti diproyeksikan UHH di Daerah Istimewa Yogyakarta mencapai 75,5 tahun, masih tertinggi dibanding provinsi lain.

Menurut Erikson (Alwisol, 2004) bahwa lanjut usia termasuk dalam tahap integritas ego dan keputusasaan. Dalam teori Erikson, orang yang sampai pada tahap ini berarti sudah cukup berhasil melewati tahap-tahap sebelumnya dan yang menjadi tugas pada usia senja ini adalah integritas dan berupaya menghilangkan putus asa dan kekecewaan. Tahap ini merupakan tahap yang paling sulit dilewati menurut pandangan sebagian orang karena mereka sudah merasa terasing dari lingkungan kehidupannya dan pada usia ini dianggap tidak bisa berbuat apa-apa lagi atau tidak berguna. Kesulitan tersebut menurut teori Erikson dapat diatasi jika di dalam diri orang yang berada dalam tahap tertinggi terdapat integritas yang memiliki arti tersendiri yaitu menerima hidup dan oleh karena itu juga berarti menerima akhir dari hidup itu sendiri (Supratiknya, 1993).

Lanjut usia yang tidak dapat mengatasi krisis akan mengalami rasa putus asa. Dorongan untuk mencapai tujuan dan keinginan yang ingin dicapai masih ada, tetapi pengikisan kemampuan karena usia seringkali mematahkan dorongan tersebut, sehingga keputusasaan acapkali menghantui. Hal tersebut bukan hanya dialami oleh individu lanjut usia, tetapi dirasakan pula oleh pasangan suami istri lanjut usia. Akan tetapi tidak semua permasalahan pada pasangan suami istri lanjut usia dipandang secara negatif. Proses penuaan pada pasangan suami istri lanjut usia yang dipandang secara positif dan optimis tersebut menggunakan konsep penuaan yang sukses. Oleh karena itu makna hidup yang diperoleh lanjut usia akan membawa lanjut usia pada kondisi tua yang sukses atau sering disebut dengan istilah successful aging (Setyabudi \& Hardywinoto, 1999).

Beberapa tugas perkembangan lanjut usia antara lain adalah menyesuaikan diri dengan masa pensiun yang akan berakibat pada berkurangnya pendapatan keluarga. Selain itu, lanjut usia juga harus menyesuaikan diri dengan kematian pasangan (Hurlock, 1999). Lanjut usia merupakan tahap di mana salah satu atau pasangan suami istri mulai memasuki masa pensiun sampai dengan salah satu pasangan meninggal dunia. Pada tahap ini tugas perkembangan keluarga lanjut usia adalah mempertahankan pengaturan hidup yang memuaskan, menyesuaikan diri terhadap pendapatan yang menurun, mempertahankan ikatan keluarga antargenerasi, meneruskan upaya memahami eksistensi mereka, dan integrasi hidup (Ali, 2009).

Akan tetapi terdapat permasalahan yang juga dihadapi lanjut usia yang tinggal 
sendiri maupun bersama pasangan yaitu mengenai kekerasan dan penelantaran. Komnas Lanjut Usia menyatakan bahwa persoalan yang mendesak dari penduduk lanjut usia adalah adanya lanjut usia yang miskin, terlantar, cacat, dan mengalami tindak kekerasan. Pada tahun 1991, jumlah lanjut usia yang terlantar diperkirakan mencapai 1.811.484 jiwa. Sementara daya tampung Panti Sosial Tresna Werdha (PSTW) masih relatif kecil (www. studibudaya.wordpress.com, 2010).

Pada pasangan suami istri lanjut usia yang masih hidup bersama berarti akan bersama-sama menghadapi usia yang semakin tua dan penurunan yang pasti akan terjadi. Semakin tua usia tersebut maka pasangannya pun tentu akan semakin tua juga. Hal tersebut menyebabkan adanya penyesuaian pada pasangan yang semakin tua pula, bahkan pasangan suami istri lanjut usia pun akan sama-sama mengalami penurunan fungsi fisik maupun psikologisnya. Keadaan tersebut tetap harus dihadapi oleh pasangan suami istri lanjut usia supaya dapat sukses mempertahankan kehidupan.

Hasil penelitian Ekowati (2008) dengan judul Penyesuaian Diri terhadap Hilangnya Pasangan Hidup pada Lansia bahwa dari 68 subjek lanjut usia yang terdiri dari 32 subjek lanjut usia pria dan 36 subjek lanjut usia wanita, subjek dalam penelitian memiliki penyesuaian diri yang positif terhadap hilangnya pasangan hidup. Bila dilihat dari setiap aspek penyesuaian diri menunjukkan aspek yang menonjol yaitu aspek penerimaan sosial. Hasil uji t menunjukkan bahwa ada perbedaan yang signifikan penyesuaian diri terhadap hilangnya pasangan hidup pada lansia antara lanjut usia pria dan lanjut usia wanita. Penyesuaian diri terhadap hilangnya pasangan hidup pada lanjut usia pria lebih tinggi dibanding lanjut usia wanita.

Kebanyakan pasangan suami istri lanjut usia hanya tinggal berdua karena ditinggalkan oleh anak-anaknya. Meskipun demikian pasangan suami istri lanjut usia yang telah berusia senja tersebut masih tetap melakukan pekerjaan demi mempertahankan kehidupannya. Tidak ada yang menghalanginya untuk beraktivitas. Pasangan suami istri lanjut usia yang tinggal terpisah dengan anaknya pun tidak menggunakan alternatif penitipan lanjut usia ataupun menyediakan tempat tinggal untuk tinggal bersama namun pasangan suami istri lanjut usia tetap tinggal di daerah tempat tinggalnya. Keputusan tersebut biasanya justru menjadi pilihan yang telah diputuskan oleh lanjut usia sendiri untuk tidak tinggal bersama anaknya.

Pasangan suami istri lanjut usia yang dapat mengatasi kehidupan bersama maka akan mencapai penuaan yang sukses yang disebut successful aging. Pada umumnya kesuksesan disimbolkan dengan kebahagiaan. Begitu pula pada lanjut usia, kebahagiaan dianggap sebagai simbol kesuksesan dalam menghadapi masa tuanya. Neugarten (Hurlock, 1999) mengatakan bahwa kepuasan hidup seperti yang ditunjukkan dengan tingkat kebahagiaan yang dialaminya, wanita cenderung lebih besar perasaan bahagianya dibanding pria pada waktu mereka telah mencapai usia lebih dari 65 tahun. Dengan demikian berarti dapat disimpulkan bahwa wanita cenderung lebih mudah mencapai penuaan yang sukses. Hal ini dapat dilihat dari kenyataan bahwa wanita biasanya lebih berumur panjang dibanding pria.

Orang yang sukses dalam proses penuaan cenderung memiliki dukungan sosial, baik emosional maupun material, yang membantu kesehatan mental, dan selama bisa tetap aktif dan produktif, mereka tidak menganggap diri mereka tua (Papalia, Olds, \& Feldman, 2009). Akan tetapi pemaknaan penuaan yang optimal tersebut dapat berbeda-beda bahkan penderitaan dan perjalanan setiap pasangan suami istri lanjut usia pun dirasakan berbeda-beda.

Hasil penelitian yang dilakukan kepada 
200 orang lanjut usia yang terdiri dari 100 orang lanjut usia dari Surabaya dan 100 orang lanjut usia dari Selangor, Malaysia oleh Hamidah dan Wrastari (2012) menyebutkan bahwa Indonesia memiliki successful aging dan dukungan sosial dalam kategori sedang dan tinggi. Bentuk dukungan sosial yang diperlukan oleh lanjut usia di Indonesia adalah dukungan informasi, baik informasi kesehatan, pendidikan, hiburan, dan informasi kegiatan sosial. Selain itu juga memerlukan dukungan sosial berupa dukungan semangat, dorongan, bantuan moral dan spiritual. Sumber dukungan sosial bagi lanjut usia di Indonesia adalah dari keluarga, sahabat, masyarakat, dan profesional. Usaha yang dilakukan lanjut usia di Indonesia untuk meraih successful aging adalah dengan bersilaturahim dan beraktivitas. Bentuk kegiatan yang dapat memberikan successful aging bagi lanjut usia di Indonesia adalah dengan membesarkan anak, membahagiakan keluarga, dan membantu orang lain.

Menjadi pasangan suami istri lanjut usia yang sukses tentunya menjadi dambaan oleh semua orang karena menjadi tua merupakan bagian dari tahap perkembangan manusia sehingga seperti pada tahap-tahap perkembangan sebelumnya bahwa keberhasilan juga menjadi impian bagi yang menjalani masa ini. Memasuki masa lanjut usia yang sukses identik dengan kesiapan untuk menghadapi perubahan dalam aspek kehidupan sosial. Banyak pasangan suami istri lanjut usia yang mampu tetap optimal di kehidupan sosial dan dapat mencapai kondisi yang dapat dikatakan sukses atau dengan kata lain bahwa pasangan suami istri lanjut usia tersebut mancapai penuaan yang sukses atau disebut dengan successful aging. Pasangan suami istri lanjut usia perlu memahami setiap keadaan supaya penuaan yang sukses tersebut dapat dijalaninya dengan baik.

Berdasarkan uraian tersebut, peneliti melihat adanya fenomena menarik untuk diangkat menjadi suatu permasalahan. Peneliti melihat adanya fenomena bahwa persentase penduduk berusia 60 tahun ke atas tumbuh lebih pesat dari kelompok umur lainnya, sebagai hasil dari peningkatan usia harapan hidup. Bahkan menurut Alimoeso (www.mizan.online. co.id) di Indonesia ini dari seluruh lanjut usia yang ada 80 persen di antaranya potensial dan hanya 20 persen saja yang kurang potensial yang membutuhkan uluran tangan pemerintah. Maka lanjut usia yang 80 persen potensial itulah yang harus menjadi perhatian pemerintah untuk melakukan pemberdayaan dan pemanfaatan lanjut usia potensial tersebut. Namun demikian, penuaan penduduk tidak harus diartikan sepenuhnya sebagai beban. Kelompok lanjut usia seharusnya lebih diakui dan didorong potensinya, sehingga para lansia dapat sehat, aktif, dan mandiri serta mencapai penuaan yang sukses.

Oleh karena itu, peneliti tertarik untuk melihat bagaimana pasangan suami istri lanjut usia menghadapi permasalahan hidup untuk kemudian mencapai penuaan yang sukses. Adapun judul penelitian ini adalah Makna Sukses di Masa Lanjut (Studi Fenomenologi pada Pasangan Suami Istri Lanjut Usia). Berdasarkan uraian latar belakang di atas, maka tujuan penelitian ini adalah untuk mengetahui makna sukses pada pasangan suami istri lanjut usia.

\section{Pengertian Penuaan yang Sukses (Successful Aging)}

Successful aging adalah suatu kondisi dimana seorang lansia tidak hanya berumur panjang tetapi juga umur panjang dalam kondisi sehat, sehingga memungkinkan untuk melakukan kegiatan secara mandiri, tetap berguna dan memberikan manfaat bagi keluarga dan kehidupan sosial. Kondisi demikian sering disebut sebagai harapan hidup untuk tetap aktif. Sebaliknya orang tidak menghendaki umur panjang, apabila umur panjang ini dilalui dalam keadaan sakit (Suardiman, 2011).

Menurut Dorris (Hamidah dan


Wrastari, 2012) mengatakan bahwa successful aging adalah kondisi yang tidak ada sakit, artinya sehat secara fisik, aman secara finansial, masih produktif dan mempunyai pekerjaan, mandiri dalam hidupnya, mampu berpikir optimis dan positif, dan masih mampu terlibat aktif dengan orang lain yang dapat memberikan makna dan dukungan secara sosial dan psikologis dalam hidupnya. Sehingga Hamidah dan Wrastari (2012) mengartikan successful aging sebagai kondisi yang seimbang antara aspek lingkungan, emosi, spiritual, sosial, fisik, psikologis, dan budaya.

Setiyartomo (2004) mendefinisikan successful aging sebagai kepuasan atas hasil pengalaman hidup yang didasarkan pada tujuan personal dalam dinamikanya dengan kehidupan sosio-kultural yang mempengaruhinya. Sedangkan Berlin Aging Study (Setiyartomo, 2004) menyebutkan bahwa successful aging dipandang sebagai kemampuan mengelola tiga indikator subjektif, yaitu;

Subjective well-being, adalah penilaian seseorang terhadap dirinya sendiri yang berhubungan dengan kebahagiaan dan kepuasan dalam hubungannya dengan lingkungan sosial.

Positive emotion, adalah bagaimana emosi yang dimunculkan seseorang berhadapan dengan situasi atau pengalaman tertentu, misalnya bangga, gembira, sedih, dan lain-lain.

Absence of loneliness, adalah perasaan subjektif yang berhubungan dengan pengalaman relasi sosial sehingga tidak merasakan kesepian.

Penuaan yang sukses (successful aging) dapat diartikan sebagai suatu kondisi fungsional lanjut usia berada pada kondisi maksimum atau optimal sehingga memungkinkan mereka bisa menikmati masa tuanya dengan penuh makna, membahagiakan, berguna, dan berkualitas. Menjadi tua yang berhasil (successful aging) merupakan tujuan dari perkembangan tahap akhir lanjut usia.
Successful aging setiap orang akan bermakna berbeda karena berbeda aktivitas. Untuk lanjut usia yang selalu aktif dan diliputi peran sosial, mungkin hal ini akan penting untuk melanjutkan atau meneruskan tingkat aktivitas yang tinggi, sedangkan seseorang yang memiliki aktivitas sedikit pada masa lalunya mungkin akan lebih bahagia pada 'kursi goyang'.

Papalia (2004) mengatakan bahwa lanjut usia yang sukses (successful agers) cenderung memiliki dukungan sosial baik emosional maupun material yang dapat membantu kesehatan mental dan sepanjang mereka merasa aktif dan produktif maka mereka tidak akan merasa sebagai orang yang sudah tua. MacArthur Foundation Research Network on USA telah mengidentifikasi tiga komponen utama dalam successful aging yaitu terhindar dari penyakit ataupun penyakit-penyakit yang menghalangi kemampuan atau kemandirian, terpeliharanya fungsi fisik dan psikologis yang tinggi, dan aktif dalam kehidupan sosial dan aktivitas yang produktif (yang dibayar ataupun tidak) yang dapat menciptakan nilai-nilai sosial (Papalia, 2004).

Lain halnya dengan pendapat Rowe dan Kahn (1997) yang mendefinisikan penuaan yang sukses (successful aging) sebagai kemampuan mengelola tiga kunci karakteristik atau perilaku. Pertama, meminimalisir resiko munculnya berbagai penyakit dan akibat yang berhubungan dengan penyakit tersebut. Kedua, mengelola secara baik fungsi-fungsi baik fisik maupun mental. Ketiga, memanfaatkan waktu yang ada secara aktif. Ketiga faktor tersebut penting dan berhubungan antara satu dengan yang lainnya sehingga membentuk kombinasi yang tersusun secara hirarki dalam membentuk successful aging.

Pendapat lain yang membahas mengenai lanjut usia sukses adalah Erikson (Suardiman, 2011) bahwa lanjut usia berhasil (successful aging) didefinisikan 
sebagai kepuasan dari dalam (inner satisfaction) daripada penyesuaian eksternal (eksternal adjustment), sedangkan tugas-tugas perkembangan lanjut usia adalah memantapkan cita integritas, satu cita hidup tentang kebermaknaan dan kepuasan.

Berdasarkan beberapa pendapat dari para ahli dapat disimpulkan bahwa penuaan yang sukses (successful aging) adalah penuaan pada lanjut usia yang mengalami suatu kondisi yang fungsional dan maksimum atau optimal, tercegah dari berbagai penyakit, serta fungsi kognitif yang tinggi, sehingga memungkinkan lanjut usia dapat menikmati masa tuanya dengan penuh makna, membahagiakan, berguna, dan berkualitas serta tetap berperan aktif dalam kegiatan sosial.

\section{Faktor-faktor yang Mempengaruhi Sukses di Masa Lanjut}

Lanjut usia yang sukses diidentikkan dengan umur panjang meskipun bukan satu-satunya kriteria dari kesuksesan di masa tua. Banyak faktor yang memberikan kontribusi pada umur panjang seseorang. Menurut Suardiman (2011) ada empat faktor yang diduga menjadi prediktor yang baik bagi umur panjang seseorang, yaitu;

Mobilitas fisik, maksudnya orang yang aktif cenderung berumur panjang.

Pendidikan, orang dengan pendidikan yang lebih tinggi cenderung lebih panjang umurnya daripada yang pendidikannya lebih rendah.

Pekerjaan, para profesional atau orang dengan pekerjaan yang hanya membutuhkan aktivitas fisik relatif kecil cenderung berumur panjang.

Aktivitas, orang yang aktif bekerja lebih panjang umurnya daripada orang yang banyak menganggur atau pensiun.

Berk (Suardiman, 2011) me-nyebutkan faktor-faktor yang mem-pengaruhi pencapaian penuaan yang sukses (successful aging), antara lain;

Optimis serta perasaan efikasi diri dalam meningkatkan kesehatan dan fungsi fisik.

Optimisasi secara selektif dengan kompensasi untuk membangun keterbatasan energi fisik dan sumber kognitif sebesar-besarnya.

Penguatan konsep diri yang meningkatkan penerimaan diri dan pencapaian harapan.

Memperkuat pengertian emosional dan pengaturan emosional diri yang mendukung makna dan menghadirkan ikatan sosial.

Menerima perubahan yang membantu perkembangan kepuasan hidup.

Perasaan spiritual dan keyakinan yang matang, harapan akan kematian dengan ketenangan dan kesabaran.

Kontrol pribadi dalam hal ketergantungan dan kemandirian.

Kualitas hubungan yang tinggi, memberikan dukungan sosial, dan persahabatan yang menyenangkan.

Masa lanjut usia merupakan masa mempertahankan kehidupan (defensive strategy) dalam arti secara fisik berusaha menjaga kesehatan agar tidak sakit-sakitan dan menyulitkan atau membebani orang lain. Pada saat itu memang terjadi berbagai penurunan status yang disebabkan oleh penurunan berbagai aspek, seperti fisiologis, psikis, dan fungsi-fungsi sensorik-motorik yang diikuti oleh penurunan fungsi fisik, kognitif, emosi, minat, sosial, ekonomi, dan keagamaan (Suardiman, 2011).

Sedangkan menurut Budiarti (2010) terjadinya penuaan yang sukses (successful aging) karena terdapat beberapa faktor yang saling berkaitan, antara lain;

Faktor fisik dan kesehatan. Pola hidup yang sehat akan membuat keadaan fisik dan kesehatan lanjut usia tetap terjaga. Pola hidup sehat yang dimaksud yaitu mengontrol pola makan, seperti menghindari makanan yang menyebabkan penyakit, mengkonsumsi nutrisi dan vitamin bagi kesehatan tubuh, rutin melakukan check-up kesehatan serta aktif dalam melakukan kegiatan olah raga untuk menjaga kesehatan fisik. 
Faktor aktivitas. Lanjut usia mampu memanfaatkan waktu luang mereka dengan melakukan aktivitas-aktivitas yang disenangi seperti aktif di kegiatan lingkungan, membantu anak-anak belajar mengaji ataupun menjadi guru les akan membuat lanjut usia merasa masih berguna baik untuk dirinya maupun orang lain.

Faktor psikologis. Sikap-sikap positif pada lanjut usia seperti menyadari akan segala kekurangan yang ada dalam dirinya, mampu menghadapi serta menyelesaikan per-masalahan pada dirinya serta tercapainya tujuan dan memaknai hidup dengan baik akan membuat lanjut usia menjalani usia senjanya dengan perasaan optimis.

Faktor sosial. Dengan adanya dukungan baik dari keluarga maupun lingkungan kepada lanjut usia untuk tetap melakukan segala kegiatan di lingkungannya akan membuat lanjut usia merasa diakui atau dihargai.

Faktor religiusitas. Rutinitas yang dilakukan lanjut usia untuk menjalankan ibadah serta mengikuti kegiatan keagamaan merupakan salah satu bentuk adanya keyakinan yang kuat akan campur tangan Tuhan atas apa yang diperolehnya dalam menjalani hidup.

\section{Aspek-aspek Penuaan yang Sukses (Successful Aging)}

Menurut Lawton (Weiner, 2003) menyebutkan bahwa penuaan yang sukses (successful aging) mempunyai empat aspek, yaitu;

Functional well. Functional well diartikan sebagai keadaan lanjut usia yang masih memiliki fungsi fisik yang baik, psikis yang baik, maupun kognitif yang baik dimana ketiga fungsi tersebut masih tetap terjaga dan mampu bekerja dengan optimal di dalamnya termasuk juga kemungkinan tercegah dari berbagai penyakit, kapasitas fungsional fisik dan kognitif yang tinggi dan terlibat aktif dalam kehidupan.

Psychological well-being. Psycholo- gical well-being merupakan kondisi individu yang ditandai dengan adanya perasaan bahagia, mempunyai kepuasan hidup, dan tidak ada gejala depresi. Kondisi tersebut dipengaruhi oleh enam fungsi psikologis yang positif yaitu;

Penerimaan diri (self acceptance). Aspek ini merupakan ciri utama kesehatan mental dan sebagai karakteristik utama dalam aktualisasi diri, berfungsi optimal, dan kematangan. Penerimaan diri yang baik ditandai dengan kemampuan menerima diri apa adanya. Kemampuan tersebut memungkinkan seseorang untuk bersikap positif terhadap diri sendiri dan kehidupan yang dijalani. Individu yang mempunyai penerimaan diri yang baik ditandai dengan bersikap positif pada diri sendiri, mengetahui serta menerima aspek-aspek yang terdapat dalam dirinya, baik positif maupun negatif dan memiliki pandangan positif terhadap masa lalu.

Hubungan baik dengan orang lain (positive relationship with other). Menurut aspek ini, individu yang tinggi atau baik ditandai dengan adanya hubungan hangat, memuaskan, dan saling percaya dengan orang lain. ia juga memiliki rasa afeksi dan empati yang kuat. Sebaliknya, individu yang hanya mempunyai sedikit hubungan dengan orang lain, sulit untuk bersikap hangat, dan enggan untuk mempunyai ikatan dengan orang lain, menandakan bahwa ia kurang baik dalam aspek ini.

Autonomy. Aspek autonomi menjelaskan mengenai kemampuan untuk menentukan diri sendiri, kemandirian, dan kemampuan untuk mengatur tingkah laku. Individu yang baik dalam aspek ini mampu menolak tekanan sosial untuk berpikir dan bertingkah laku dengan cara tertentu serta dapat mengevaluasi dirinya sendiri dengan standar personal. Sebaliknya individu yang kurang baik dalam aspek ini akan memperhatikan harapan dan evaluasi orang lain, membuat keputusan berdasarkan penilaian orang lain dan cenderung berharap konformis.

Kontrol diri pada lingkungan (control 
over one's environment)

Individu yang baik dalam aspek ini mampu untuk memanipulasi keadaan sehingga sesuai dengan kebutuhan dan nilai-nilai pribadi yang dianutnya dan mampu untuk mengembangkan diri secara kreatif melalui aktivitas fisik maupun mental. Sebaliknya individu yang kurang baik dalam aspek ini akan menampakkan ketidakmampuan untuk mengatur kehidupan sehari-hari dan kurang memiliki kontrol terhadap lingkungan luar.

Tujuan hidup (purpose in live). Individu yang baik dalam aspek ini mempunyai perasaan bahwa kehidupan saat ini dan masa lalunya memiliki keberartian, memegang kepercayaan yang memberikan tujuan hidup, dan mempunyai target yang ingin dicapai dalam kehidupan, maka ia dapat dikatakan mempunyai tujuan hidup yang baik. Sebaliknya individu yang tidak baik dalam aspek ini mempunyai perasaan bahwa tidak ada tujuan yang ingin dicapai dalam hidup, tidak melihat adanya manfaat dalam masa lalu kehidupannya, dan tidak mempunyai kepercayaan yang membuat hidup lebih berarti.

Pertumbuhan pribadi (personal growth). Aspek pertumbuhan pribadi menjelaskan mengenai kemampuan individu untuk mengembangkan potensi dalam diri dan berkembang sebagai seorang manusia. Aspek ini dibutuhkan oleh individu agar dapat optimal dalam berfungsi secara psikologis. Salah satu hal penting dalam aspek ini adalah adanya kebutuhan untuk mengaktualisasikan diri, misalnya dengan keterbukaan terhadap pengalaman. Individu yang baik dalam aspek ini mempunyai perasaan untuk terus berkembang, melihat diri sendiri sebagai sesuatu yang bertumbuh, menyadari potensi yang terdapat di dalam dirinya, dan mampu melihat peningkatan dalam diri dan tingkah laku dari waktu ke waktu. Sebaliknya, individu yang tidak baik dalam aspek ini akan menampilkan ketidakmampuan untuk mengembangkan sikap dan tingkah laku baru, mempunyai perasaan bahwa ia adalah seorang pribadi yang stagnan, tidak tertarik dengan kehidupan yang dijalani.

\section{Selection}

Optimatization

Compensation (SOC). Model SOC merupakan model pengembangan yang mendefinisikan proses universal regulasi perkembangan. Proses ini bervariasi fenotipe biasanya, tergantung pada konteks sosio-historis dan budaya, domain fungsi, serta pada tingkat analisis. Mengambil perspektif aksi-teoritis, seleksi, optimis, dan kompensasi mengacu pada proses pengaturan, mengejar, dan me-melihara tujuan pribadi.

Seleksi, mengacu pada pengembangan, menguraikan, dan berkomitmen untuk tujuan pribadi. Optimasi, untuk mencapai hasil yang diinginkan dalam domain yang dipilih, berarti tujuan yang relevan perlu diperoleh, diterapkan, dan halus. Kompensasi, pemeliharaan fungsi positif dalam menghadapi kerugian mungkin sama pentingnya bagi penuaan sukses sebagai fokus pertumbuhan yang berkelanjutan. Primary and Secondary Control

Dalam semua kegiatan yang relevan dengan kelangsungan hidup, individu berjuang untuk kontrol dalam hal mewujudkan hasil yang diinginkan dan mencegah yang tidak diinginkan. Kecenderungan motivasi paling mendasar dan universal berhubungan dengan dasar ini berusaha untuk mengendalikan lingkungan, atau dalam istilah yang lebih spesifik, untuk menghasilkan konsistensi antara perilaku dan peristiwa di lingkungan. Hal ini disebut sebagai primary control. Sedangkan secondary control merujuk kepada kemampuan seseorang untuk mengatur keadaan mental, emosi, dan motivasi.

Berdasarkan uraian tersebut dapat disimpulkan bahwa setiap lanjut usia mempunyai potensi untuk meraih sukses di masa lanjut. Lanjut usia perlu memahami setiap keadaan supaya penuaan yang sukses tersebut dapat dijalaninya dengan baik. 


\section{Metode Penelitian}

Desain penelitian yang digunakan dalam penelitian ini adalah penelitian kualitatif dengan pendekatan fenomenologi. Metode penelitian kualitatif memungkinkan peneliti untuk memahami fenomena tentang apa yang dialami oleh subjek penelitian misalnya perilaku, persepsi, motivasi, tindakan, dan lain-lain dengan cara deskripsi dalam bentuk kata-kata dan bahasa pada suatu konteks khusus yang alamiah dan dengan memanfaatkan berbagai metode alamiah (Moleong, 2010). Peneliti memilih metode penelitian kualitatif karena peneliti ingin mengetahui bagaimana makna sukses pada pasangan suami istri lanjut usia di masa lanjut.

Sedangkan pendekatan yang digunakan dalam penelitian ini adalah pendekatan fenomenologi. Pendekatan fenomenologi berorientasi untuk memahami, menggali, dan menafsirkan arti dan peristiwa-peristiwa, dan hubungan dengan orang-orang yang biasa dalam situasi tertentu. Penelitian dengan menggunakan pendekatan fenomenologis ini biasa disebut dengan penelitian yang menggunakan pengamatan terhadap fenomena-fenomena atau gejala-gejala sosial yang alamiah yang berdasarkan kenyataan lapangan (empiris) (Moleong, 2010). Oleh karenanya, dalam penelitian ini juga diupayakan dengan meninjau secara langsung objek penelitian pada pasangan suami istri lanjut usia. Hal ini dimaksudkan agar mendapatkan data yang general dan akurat, sehingga dapat mencapai hasil yang maksimal serta penelitian ini dapat dinilai sebagai karya penelitian yang baik.

Subjek dalam penelitian ini sebanyak dua pasang suami istri lanjut usia. Pengambilan subjek dalam penelitian ini menggunakan teknik purposive sampling yaitu teknik pengambilan subjek dengan karakteristik tertentu (Sugiyono, 2008). Adapun karakteristik subjek dalam penelitian ini adalah pasangan suami istri lanjut usia dengan usia sekitar 65 tahun hingga 80 tahun. Subjek tidak tinggal serumah dengan anaknya, sehingga lanjut usia hanya tinggal dengan pasangannya.

Metode pengumpulan data yang digunakan dalam penelitian ini yaitu wawancara, observasi, dan dokumentasi. Teknis analisis data menggunakan tiga langkah yaitu reduksi data, penyajian data, dan penarikan kesimpulan/verifikasi. Validitas dan reliabilitas menggunakan triangulasi dengan sumber sebagai uji keabsahan data. Triangulasi dengan sumber yaitu membandingkan dan mengecek balik derajat kepercayaansuatu informasi yang diperoleh melalui waktu dan alat yang berbeda dalam metode kualitatif.

\section{Hasil Penelitian dan Pembahasan}

\section{Subjek 1}

Pasangan suami istri Mbah $\mathrm{Ju}$ dan Mbah Mus menikah sejak sekitar 60 tahun yang lalu. Saat ini Mbah Ju berusia 80 tahun dan Mbah Mus berusia 76 tahun. Pasangan suami istri Mbah Ju dan Mbah Mus dikaruniai 3 orang anak, 6 orang cucu, dan 9 orang cicit. Aktivitas keseharian Mbah Ju adalah sebagai tukang cuci motor di suatu dealer Babarsari sejak 30 tahun yang lalu, sedangkan Mbah Mus sebagai penjual makanan (bubur dan lauk pauk) di rumah setiap pagi sejak 23 tahun yang lalu.

Sebelum Mbah Ju dan Mbah Mus menekuni pekerjaan tersebut, sempat berpindah-pindah kerja. Ilmu yang terbatas dan keadaan ekonomi yang terbatas pula tidak menghalanginya untuk tetap bekerja. Hal tersebut terjadi saat anak-anaknya masih bersekolah. Setelah anak-anaknya sudah berkeluarga dan tidak bertempat tinggal dengan Mbah Ju dan Mbah Mus akhirnya pekerjaannya pun mulai menetap. Hal ini sudah berjalan sekitar 23 tahun yang lalu. Jauh dari anak-anak pun semakin lengkap ketika anak ketiganya meninggal dunia. Ia adalah satu-satunya anak laki-laki dan abnormal di keluarga.

Pasangan suami istri Mbah $\mathrm{Ju}$ dan Mbah Mus mengartikan kesuksesan adalah sebagai keadaan ketika bisa membeli rumah, dapat membenahi rumah, dan dapat 
makan setiap hari. Kesuksesan juga diartikan ketika sedang mendapatkan hasil dari usahanya. Usaha yang dimaksud adalah dengan bekerja ataupun berjualan. Banyak orang mengaitkan kesuksesan identik dengan keberhasilan finansial seperti pada pasangan suami istri Mbah Ju dan Mbah Mus. Kesuksesan yang dirasakan pasangan suami istri Mbah $\mathrm{Ju}$ dan Mbah Mus diukur dari pendapatannya ketika bekerja, khususnya dari hasil berjualan yang dilakukan Mbah Mus. Sehingga jika dilihat dari jaman sekarang ini, pasangan suami istri Mbah Ju dan Mbah Mus mengalami penurunan. Dulu, saat berjualan pasti mendapatkan uang dan keuntungan yang dapat disisihkan tetapi pada saat ini berjualan mulai tidak lancar, selain karena keuntungan yang didapat tidak sebanyak dulu, harga-harga kebutuhan saat ini pun mahal sehingga jarang bisa menyisihkan uang. Meskipun tidak banyak keuntungan yang didapat, tetapi pasangan suami istri Mbah Ju dan Mbah Mus masih dapat menyisihkan untuk kebutuhan makan sehari-hari.

Kesuksesan juga diartikan pasangan suami istri Mbah Ju dan Mbah Mus yang merasa senang memiliki keluarga yang rukun meskipun kini anak-anaknya tidak tinggal serumah lagi dengan pasangan suami istri Mbah Ju dan Mbah Mus. Begitu pula dengan tetangga pun, pasangan suami istri Mbah $\mathrm{Ju}$ dan Mbah Mus dapat menghormati dan saling tolong-menolong ketika membutuhkan meskipun pasangan suami istri Mbah Ju dan Mbah Mus adalah satu-satunya pasangan lanjut usia yang masih ada di lingkungan tempat tinggalnya.

Tujuan hidup pasangan suami istri Mbah Ju dan Mbah Mus yaitu ingin masuk surga sehingga pasangan suami istri Mbah $\mathrm{Ju}$ dan Mbah Mus pun rajin ibadah khususnya sholat. Selain itu, apabila mempunyai uang, pasangan suami istri Mbah Ju dan Mbah Mus ingin mempunyai apapun tetapi jika tidak dapat memenuhinya, pasangan suami istri Mbah $\mathrm{Ju}$ dan Mbah Mus tidak memaksakan diri karena menyadari bahwa dirinya sudah tua dan tidak kuat lagi seperti dulu.

\section{Subjek 2}

Pasangan suami istri Mbah Izam dan Mbah Nem telah menikah sejak sekitar 50 tahun yang lalu. Mbah Izam lahir pada 5 Juni 1944 sehingga pada saat ini berusia 72 tahun, sedangkan Mbah Nem adalah kelahiran tahun 1948 sehingga pada saat ini berusia 69 tahun. Pasangan suami istri Mbah Izam dan Mbah Nem dikarunia 2 orang anak, perempuan dan laki-laki, serta 3 orang cucu. Saat ini aktivitas keseharian pasangan suami istri Mbah Izam dan Mbah Nem adalah sebagai petani. Sebelum pasangan suami istri Mbah Izam dan Mbah Nem menekuni pekerjaan sebagai petani sempat berganti-ganti pekerjaan. Mbah Izam pun sempat merantau ke Sumatra untuk bekerja. Ilmu yang terbatas dan keadaan ekonomi yang terbatas pula tidak menghalangi pasangan suami istri Mbah Izam dan Mbah Nem untuk tetap bekerja.

Pasangan suami istri Mbah Izam dan Mbah Nem memaknai kesuksesan adalah ketika mengasuh anak bisa tentram, pendapatan harian lancar, dan besar kecilnya yang diterima terserah Alloh yang menentukan. Untuk mencapai kesuksesan, ketika bekerja harus ditelateni dan ditekuni, juga melibatkan Alloh karena jika Alloh mengijinkan maka dengan begitu seseorang akan meraih kesuksesan. Meskipun sebenarnya yang dapat menilai kesuksesan seseorang adalah orang lain. Supaya dapat meraih sukses maka seseorang harus mengerjakan apa yang menjadi tujuannya, dengan ditekuni juga disyukuri maka dalam diri seseorang pun akan muncul rasa sukses. Apabila pekerjaan yang digelutinya banyak maka harus ditekuni satu per satu.

Kesuksesan juga diartikan oleh pasangan suami istri Mbah Izam dan Mbah Nem ketika keduanya saling mendukung pekerjaan yang dilakukan. Usaha untuk mencapai kesuksesan menurut pasangan suami istri Mbah Izam dan Mbah Nem yaitu ketika bekerja harus ditelateni dan ditekuni, tidak lupa juga untuk melibatkan 
Alloh karena jika Alloh mengijinkan maka dengan begitu seseorang akan meraih kesuksesan. Supaya dapat meraih sukses maka seseorang harus mengerjakan apa yang menjadi tujuannya, dengan ditekuni juga disyukuri maka dalam diri seseorang pun akan muncul rasa sukses.

Tujuan hidup pasangan suami istri Mbah Izam dan Mbah Nem adalah bisa mengasuh anak dan cucu supaya nanti suatu hari anak dan cucu bisa mengasuh Mbah Izam dan Mbah Nem. Saat ini pasangan suami istri Mbah Izam dan Mbah Nem masih bekerja dan diharapkan besok anak dan cucu bisa menikmati hasilnya. Tujuan pasangan suami istri Mbah Izam dan Mbah Nem adalah untuk mendapatkan rejeki untuk anak dan cucu supaya suatu hari anak dan cucu dapat bergantian mengasuh Mbah Izam dan Mbah Nem. Hasil yang didapatkan dari pekerjaan pasangan suami istri Mbah Izam dan Mbah Nem nantinya juga akan dibagikan untuk anak dan cucu. Saat bisa berbagi dengan anak dan cucu, pasangan suami istri Mbah Izam dan Mbah Nem akan merasakan kepuasan.

\section{Pembahasan}

Penelitian ini bertujuan untuk mengetahui bagaimana makna sukses di masa lanjut pada pasangan suami istri lanjut usia. Berdasarkan data yang didapat dari hasil penelitian, peneliti akan mendiskripsikan mengenai makna sukses pada pasangan suami istri lanjut usia.

Sukses di masa lanjut atau sering disebut dengan istilah successful aging merupakan suatu keadaan penuaan pada lanjut usia yang mengalami suatu kondisi yang fungsional dan maksimum atau optimal, tercegah dari berbagai penyakit, serta fungsi kognitif yang masih baik sehingga memungkinkan lanjut usia tersebut dapat menikmati masa tuanya dengan penuh makna, membahagiakan, berguna, dan berkualitas serta tetap berperan aktif dalam kegiatan sosial.

Kesuksesan tidak terjadi dengan begitu saja. Ada proses yang harus dihadapi dengan liku-likunya. Setiap individu mempunyai pengalaman yang berbedabeda dalam rentang kehidupannya. Ukuran kesuksesan bersifat subjektif dan tergantung dari standar yang dimiliki oleh setiap individu tersebut. Bahkan masih banyak yang belum tahu betul makna dari sebuah kesuksesan. Sebagian besar orang selalu mengaitkan kesuksesan hidup dengan keberhasilan secara finansial.

Sebagian orang mengartikan kesuksesan sebagai suatu keadaan ketika bisa membeli rumah, dapat membenahi rumah, dan dapat makan setiap hari, hal tersebut dapat disebut sebagai kesuksesan (S1: 21-23 W2). Terkadang kesuksesan juga diukur dari pendapatan yang diperoleh dari bekerja, khususnya dari hasil berjualan (S1: 45-47 W2). Sedangkan pendapat lain mengatakan bahwa sesungguhnya yang dapat menilai seseorang tersebut sukses atau tidak adalah orang lain. Sukses diartikan ketika seseorang dapat mengasuh anak dan cucu dengan tentram, pendapatan yang diperoleh sehari-hari lancar meskipun tidak mengetahui banyak tidaknya yang diperoleh karena sudah ditentukan oleh Alloh (S2: 219-224 W2).

Pasangan hidup merupakan salah satu yang didambakan oleh setiap orang untuk meraih kesuksesan, karena pada dasarnya manusia merupakan makhluk sosial yang tidak dapat hidup sendiri tanpa bantuan orang lain. Setiap manusia pastinya membutuhkan orang lain sebagai teman hidupnya atau bahkan pasangan hidupnya untuk berbagi suka maupun duka. Pasangan hidup tidak hanya dibutuhkan untuk menyalurkan kasih sayang antara laki-laki dengan perempuan, tetapi lebih dari itu adalah untuk menjaga kelangsungan hidup serta meraih kesuksesan hidup di dunia maupun di akhirat. Agama telah menjelaskan bahwa Tuhan telah menciptakan manusia berpasang-pasangan.

"Hai manusia, sesungguhnya Kami menciptakan kamu dari seorang laki-laki dan seorang perempuan dan menjadikan 
kamu berbangsa-bangsa dan bersuku-suku supaya kamu saling kenal-mengenal. Sesungguhnya orang yang paling mulia di antara kamu di sisi Alloh ialah orang yang paling taqwa di antara kamu. Sesungguhnya Alloh Maha Mengetahui lagi Maha Mengenal." (QS. Al-Hujurat: 13)

Pada penelitian ini, pasangan dapat dikatakan sebagai teman hidup yang dapat menjaga keberlangsungan hidupnya. Terlihat pada kedua pasangan subjek bahwa setelah mereka tidak tinggal bersama anak-anaknya lagi, mereka tetap harus memenuhi sendiri kebutuhan seharihari, khususnya makan setiap hari. Oleh karena itu, kedua pasangan masing-masing akan berhenti bekerja apabila di antara mereka sudah tidak lagi bekerja.

Hal inipun tidak membutuhkan jalan yang mudah. Kekurangan dari masingmasing pasangan masih dapat diterima seperti halnya ketika pasangan mulai mengalami penurunan fungsi indera pendengaran (S1: 637-638 S2). Tidak hanya hal itu, perbedaan pendapat dengan pasangan lanjut usia juga tidak mudah terselesaikan apabila pasangan tidak ada. Sehingga, pasangan hidup sangatlah dibutuhkan, khususnya pada lanjut usia yang tidak lagi tinggal bersama anakanaknya. Pasangan suami istri lanjut usia pun harus mau dan mampu menjalani kehidupannya bersama berdua, menyelesaikan masalah bersama, bahkan memenuhi kebutuhan hidup setiap hari. Oleh karena itu, dalam penelitian ini pasangan dapat membantu untuk pencapaian kesuksesan di masa lanjut atau sering disebut dengan successful aging.

Selain itu, aktivitas atau pekerjaan juga dianggap hal penting oleh setiap orang yang mendambakan kesuksesan. Tidak dapat dipungkiri bahwa manusia tidak dapat bertahan hidup tanpa aktivitas atau pekerjaan, karena setiap orang mempunyai kebutuhan dan cita-cita sehingga untuk mewujudkannya manusia harus bergerak untuk bekerja atau beraktivitas. Hal tersebut tidak hanya pada anak muda, orang yang sudah tua pun harus demikian.

Aktivitas atau pekerjaan tersebut nantinya akan mengantarkan seseorang menuju apapun yg telah dicita-citakan. Terkadang aktivitas atau pekerjaan yang harus dijalani tidaklah mudah. Ada likulikunya untuk akhirnya bertahan atau melawan. Bahkan terkadang perjuangan itu pun juga tidak sebentar, butuh waktu yang lama untuk kemudian mendapatkan yang dicitakan.

Pepatah mengatakan bahwa orang yang telah tua adalah orang yang telah banyak makan garam. Artinya, bahwa orang lanjut usia adalah orang yang telah mempunyai banyak pengalaman. Begitu pula dengan kedua pasangan suami istri lanjut usia dalam penelitian ini. Tidak sedikit pengalaman yang telah dilewati, sejak usia masih muda hingga kini telah lanjut usia.

Hal yang ditemukan dalam penelitian ini bahwa pasangan suami istri lanjut usia memaknai kesuksesan sebagai hasil dari sebuah aktivitas atau kesibukan (S1: 21-23 W2). Sukses juga tidak akan diperoleh pada orang yang menganggur (S2: 332 W2) . Menurut Hurlock (1980) bahwa lanjut usia yang secara finansial terjamin, dapat memanfaatkan waktu bebasnya untuk halhal yang konstruktif, merasa bahagia dengan kontak sosialnya, dan dapat mengembangkan jasa-jasanya bagi kepentingan orang lain, ia akan dapat bertahan pada konsep diri yang superior, tetap termotivasi tinggi, dan merasa bahagia dengan hidupnya.

Berdasarkan analisis deskriptif diperoleh gambaran bahwa kedua subjek pasangan suami istri lanjut usia mempunyai makna sukses masing-masing. Pada kedua subjek tersebut telah dapat memaknai kesuksesan dikarenakan kedua pasangan tersebut memenuhi keempat aspek successful aging yang dinyatakan oleh Lawton (Weiner, 2003) yaitu functional well, psychological well-being, selection optimatization compensation (SOC), dan primary and secondary control.

Aspek penuaan sukses atau successful 
aging yang pertama adalah functional well yang diartikan sebagai keadaan lanjut usia yang masih memiliki fungsi fisik yang baik, psikis yang baik, maupun kognitif yang baik di mana ketiganya masih tetap terjaga dan mampu bekerja dengan optimal, termasuk juga kemungkinan tercegah dari berbagai penyakit serta terlibat aktif dalam kehidupan. Pada penelitian ini, kedua subjek pasangan suami istri lanjut usia dapat dikatakan berhasil menjaga ketiga fungsi yang dimilikinya yaitu fungsi fisik, psikis, dan kognitif, serta mampu bekerja optimal dan tercegah dari berbagai penyakit. Hal tersebut dilihat dari perjalanan hidup kedua subjek pasangan suami istri lanjut usia. Perjalanan hidup yang dilewati tidak tiba-tiba membawanya kepada keberhasilan. Terkadang untuk mencapai keberhasilan tersebut harus melewati liku-liku kehidupan seperti halnya berpindah-pindah kerja (S1: $634 \mathrm{~W} 1)$.

Dalam hal ini kesehatan juga menjadi hal penting dalam meraih kesuksesan di masa tua mengingat bahwa masa tua adalah masa di mana seseorang mulai mengalami kemunduran, salah satunya adalah fungsi kesehatan. Akan tetapi tidak semua pasangan suami istri lanjut usia benar-benar akan mengalami kemunduran dalam hal kesehatan karena sebagian di antaranya justru tidak pernah menderita suatu penyakit yang parah (S1: 1147 W1). Bahkan sebagian pasangan suami istri lanjut usia justru mengaku bahwa bukan sakit yang dirasakan tetapi hanyalah sebatas kelelahan yang artinya harus beristirahat selama satu atau dua hari (S2: 153-155 W2).

Aspek yang kedua yaitu psychological well-being atau ke-sejahteraan psikologis merupakan kondisi di mana individu atau lanjut usia merasa puas dengan kehidupannya baik kehidupan di masa lalu maupun kehidupan di masa mendatang. Psychological well-being berhubungan dengan positive relationship with other (hubungan baik dengan orang lain). Gaya hidup lanjut usia yang aktif di dalam organisasi dan mengikuti pertemuan akan terlihat lebih puas hidupnya daripada hanya menganggur di rumah.

Pada sebagian pasangan suami istri lanjut usia, tidak melakukan suatu akivitas atau pekerjaan justru membuat badan terasa sakit (S1: 1342-1343 W1). Hal ini karena pasangan suami istri terbiasa bekerja sejak masa mudanya. Bahkan sempat dikatakan oleh pasangan suami istri Mbah Izam dan Mbah Nem bahwa orang sukses bukanlah yang hanya menganggur di rumah tetapi mempunyai pekerjaan (S2: $332 \mathrm{~W} 2)$.

Pasangan suami istri lanjut usia tidak terlepas dari kehidupan bermasyarakat, terlebih ketika seseorang itu adalah yang paling tua di lingkungan tersebut. Menjaga hubungan baik dengan tetangga adalah hal yang seharusnya dilakukan. Menjaga hubungan baik dengan tetangga dapat ditunjukkan dengan cara masih melibatkan diri dalam acara-acara di lingkungan masyarakat seperti arisan (S1: 1219-1220 W2). Menjaga hubungan baik dengan tetangga juga dapat ditunjukkan dengan saling membantu pekerjaan dengan tetangga (S2: 1119-1121 W2). Meskipun telah lanjut usia namun tidak terbatas untuk melakukan kebaikan kepada tetangga, seperti halnya saat ada tetangga yang sekiranya harus dibantu maka pasangan suami istri lanjut usia yang masih kuat pun harus dapat membantu,bukan justru membenci tetangga tersebut (S2: 979-985 W2).

Masih mengikuti suatu organisasi meskipun telah lanjut usia juga dapat dikatakan sebagai wujud menjaga hubungan baik dengan orang lain. Hal ini seperti yang dilakukan oleh Mbah Izam dalam penelitian ini. Meskipun telah berusia lanjut, Mbah Izam justru ditunjuk sebagai ketua perkebunan dalam organisasi tersebut (S2: 1112-1113 W2). Hal ini juga sesuai dengan konsep teori kepuasan hidup yang dikemukakan oleh Suardiman (2011) bahwa kesejahteraan psikologis lanjut usia dipengaruhi oleh gaya hidup aktif.

Sukses di masa lanjut atau successful 
aging merupakan tujuan dari perkembangan tahap akhir lanjut usia juga berkaitan erat dengan kebahagiaan. Erikson (Hurlock, 1999) mengatakan bahwa orang yang berusia lanjut yang telah mencapai standar yang telah ditetapkan saat masih muda dan mereka percaya bahwa keadaannya sesuai dengan keadaan pribadi ideal maka mereka akan mengalami kebahagiaan, sebaliknya bahwa orangorang lanjut usia yang merasa gagal dengan harapan-harapan yang dibuat saat masih muda dan putus asa dengan keadaannya, menyadari bahwa kesempatan mereka untuk sukses telah hilang dan mereka cenderung tidak akan bahagia.

Kebahagiaan pada lanjut usia juga dipengaruhi oleh penerimaan diri yang baik pada masa lalu saat masih muda maupun sekarang saat sudah lanjut usia. Selain oleh penerimaan diri (self acceptance), kebahagiaan juga dipengaruhi oleh achievement. Adanya perbedaan achievement antara lanjut usia satu dengan lainnya juga menyebabkan adanya perbedaan dalam aspek psychological wellbeing.

Aspek selanjutnya yaitu selection optimatization compensation (SOC) yang dijadikan kunci untuk menuju lanjut usia yang sukses adalah dengan menggunakan waktu sebaik mungkin untuk melakukan hal yang bermakna. Kegiatan yang dilakukan untuk mengisi waktu luang dan menutupi perasaan menganggur cenderung mengurangi rasa tidak bahagia pada lanjut usia. Akhirnya Schultz (Suardiman, 2011) berpendapat bahwa seseorang dikatakan memiliki successful aging yang baik apabila mereka tetap mampu untuk memelihara kemampuan mengontrol dalam setiap sendi kehidupannya.

Hal tersebut dapat ditunjukkan dengan keterlibatan seseorang di dalam kehidupan bermasyarakat di sekitar tempat tinggalnya, seperti halnya ketika di pedesaan hampir semua penduduk di pedesaan memiliki sawah, aktivitas dapat diciptakannya sendiri di sawah tersebut (S2: 666-672
W2). Atau ketika di perkotaan yang banyak terdapat warung, lanjut usia yang mempunyai warung dapat memanfaatkannya sebagai sarana supaya tidak menganggur (S1: 1376-1380 W1). Adanya pekerjaan yang dilakukan setelah memasuki masa lanjut memungkinkan lanjut usia untuk tetap memiliki pencapaian successful aging khususnya pada aspek selection optimatization compensation (SOC).

Aspek yang terakhir yaitu primary and secondary control yang dapat diartikan sebagai keinginan seseorang untuk tetap memiliki motivasi yang kuat serta usaha untuk bisa mengendalikan lingkungan, atau dalam istilah yang lebih spesifik, untuk menghasilkan konsistensi antara perilaku dan peristiwa di lingkungan. Hal ini disebut dengan primary control. Sedangkan secondary control lebih kepada kemampuan seseorang untuk mengatur keadaan mental, emosi, dan motivasi.

Aspek primary and secondary control dalam pencapaian successful aging pada lanjut usia dipengaruhi oleh kehidupan sehari-hari di mana lanjut usia lebih bisa menempatkan diri terhadap lingkungan seperti tetap aktif dalam kehidupan bermasyarakat sehingga memungkinkan bahwa lanjut usia dapat melakukan pencapaian successful aging dengan baik.

Hal yang ditemukan dalam penelitian ini bahwa pasangan suami istri lanjut usia memaknai kesuksesan sebagai hasil dari sebuah aktivitas atau kesibukan (S1: 21-23 W2). Sukses juga tidak akan diperoleh pada orang yang menganggur (S2: $332 \mathrm{~W} 2$ ). Menurut Hurlock (1980) bahwa lanjut usia yang secara finansial terjamin, dapat memanfaatkan waktu bebasnya untuk halhal yang konstruktif, merasa bahagia dengan kontak sosialnya, dan dapat mengembangkan jasa-jasanya bagi kepentingan orang lain, ia akan dapat bertahan pada konsep diri yang superior, tetap termotivasi tinggi, dan merasa bahagia dengan hidupnya.

Kedua subjek pasangan suami istri 
lanjut usia merupakan pasangan yang giat bekerja. Kedua pasangan tersebut menyatakan bahwa mereka menerima keadaan yang telah dijalani maupun yang sedang dijalaninya. Kedua subjek pasangan suami istri lanjut usia menerima keadaan dengan bersyukur dan mengembalikan pada ajaran agama atau percaya akan kuasa Alloh tentang apa yang mereka dapatkan sekarang.

Sebagai individu yang memasuki masa lanjut usia, secara umum tak banyak hal-hal penting yang ada di dalam pikiran mereka. Harapan mereka lebih banyak ditujukan untuk menjadi pribadi yang mandiri karena takut merepotkan dan menambah beban anak-anak atau keluarga. Tujuan hidup kedua subjek pasangan suami istri lanjut usia tersebut lebih mengarah kepada harapan untuk tetap sehat, dapat membahagiakan anak cucu, serta tetap bisa mandiri tanpa membebani anak cucu serta tetangga (S1: 264-269 W2) (S2: 445-448 W2). Hal ini menjadi wajar karena faktor usia memiliki perubahan tugas perkembangan khususnya dalam mengarahkan tujuan hidupnya, di mana terdapat perubahan cara hidup pada individu yaitu dari usia pertengahan ke usia lanjut (Duvall, 1985).

Kedua subjek pasangan suami istri lanjut usia tersebut tidak mengharapkan kerja keras yang memaksakan tubuh karena mereka menyadari telah berusia lanjut sehingga dalam bekerja pun sekuat dan semampunya saja.

Jika dilihat dari pendidikan, kedua subjek pasangan suami istri lanjut usia sama-sama tidak berpendidikan tinggi namun hal tersebut tidak menjadi penghalang mereka untuk memilih pekerjaan. Pendidikan yang tidak tinggi justru membuat kedua subjek pasangan suami istri lanjut usia dapat berganti-ganti pekerjaan meskipun pekerjaan yang dilakukan pun seadanya hingga kini mereka bertahan hidup dengan pekerjaan bertani (S2: $211 \mathrm{~W} 1$, S2: $137 \mathrm{~W} 2)$, berjualan (S1:126-127 W1), dan menjadi buruh cuci motor (S1: $164 \mathrm{~W} 1)$.

Pekerjaan yang dilakukan merupakan sebagian usaha kedua subjek pasangan suami istri lanjut usia untuk melanjutkan hidup tanpa berpangku tangan di dalam rumah. Usaha tersebut menunjukkan bahwa kedua subjek pasangan suami istri lanjut usia menyadari akan tanggung jawab yang besar untuk kelangsungan hidup mereka sehingga nantinya akan mencapai masa lanjut usia yang sukses.

Dengan demikian, dapat dikatakan bahwa kedua subjek pasangan suami istri lanjut usia masih memiliki kemampuan dalam mengadakan hubungan yang baik dengan orang lain. Kesehatan fisik yang cukup juga dimiliki kedua subjek pasangan suami istri lanjut usia tersebut, ditunjukkan dengan aktivitas rutin yang masih dilakukan pasangan suami istri Subjek 1 yaitu Mbah Ju bekerja di dealer untuk cuci motor dengan mengendarai sepeda setiap hari (S1: 172-173 W1) dan Mbah Mus berjualan di rumah setiap pagi (S1: 252 W2). Begitu pun pada pasangan suami istri Subjek 2 Mbah Izam dan Mbah Nem, pasangan ini keduanya beraktivitas di sawah sebagai petani (S2: $211 \mathrm{~W} 1$, S2: 137 W2).

Menjadi lanjut usia bukanlah hal yang mudah, banyak perubahan yang terjadi seiring dengan bertambahnya usia. Hal ini juga terjadi pada kedua subjek pasangan suami istri lanjut usia yaitu adanya penurunan kemampuan yang dirasakan oleh kedua pasangan tersebut. Mereka samasama mengakui bahwa mereka telah mengurangi kemampuannya dalam bekerja. Misalnya kini mereka bekerja hanya semampu dan sekuatnya saja. Pada Subjek 1, Mbah Ju mengalami penurunan fungsi pendengaran.

Hidup sebagai pasangan suami istri lanjut usia yang hanya tinggal berdua adalah konsekuensi yang harus dijalani oleh kedua pasangan karena keduanya mau tidak mau harus mengurus hidupnya berdua saja. Begitu pun dalam memutuskan masalah, kedua pasangan tersebut tentunya 
memiliki keterikatan dengan pasangan masing-masing supaya tercapai penyelesaian masalah dengan baik.

Berdasarkan hasil analisis menunjukkan bahwa untuk mencapai kesuksesan di masa lanjut bukanlah hal yang mudah mendapatkannya. Butuh perjuangan panjang yang harus dijalani karena tidak semua orang dapat menaklukkan beratnya cobaan sebelum akhirnya mencapai penuaan yang sukses. Hubungan positif dengan anak dan cucu masih dimiliki meskipun anak dan cucu tidak lagi tinggal bersama subjek dalam satu rumah. Kedua subjek pasangan suami istri lanjut usia masih berpartisipasi pada aktivitas di luar rumah meskipun subjek membatasi diri karena faktor usia. Secara keseluruhan, lanjut usia yang sukses terkait dengan fungsi yang masih baik di dalam diri, kesejahteraan psikologi, menggunakan waktu sebaik mungkin untuk melakukan hal bermakna, dan keinginan untuk tetap memiliki motivasi dan mengendalikan lingkungan serta kemampuan mengatur mental, emosi, dan motivasi.

Kesuksesan merupakan harapan semua orang, termasuk untuk meraih sukses di masa lanjut. Kesuksesan tidak bisa terwujud secara tiba-tiba, butuh proses untuk mencapainya. Ukuran kesuksesan bersifat subjektif karena penilaian terhadap pencapaian dinilai berbeda-beda. Tidak terkecuali bagi lanjut usia yang sudah banyak makan asam garam kehidupan, dengan pengalaman hidup yang telah dijalani, termasuk pada kedua subjek pasangan suami-istri lanjut usia dalam penelitian ini. Tidak mengenal umur ataupun pekerjaan, setiap orang tentunya ingin meraih kesuksesan. Sukses dapat diartikan sebagai tujuan akhir bagi banyak orang yang menjalani suatu aktivitas karena semua hal yang dilakukan harus mengarah pada satu tujuan yaitu kesuksesan. Seseorang yang memiliki kecenderungan untuk meraih sukses yang kuat dibanding dengan menghindari kegagalan.

Berdasarkan hasil penelitian yang telah dijelaskan di atas maka dapat disimpulkan bahwa kedua subjek pasangan suami istri lanjut usia dalam penelitian ini sudah memenuhi faktor yang dapat mempengaruhi sukses di masa lanjut, baik dengan melibatkan orang lain maupun tanpa keterlibatan orang lain. usia yang telah lanjut tidak menjadi penghalang bagi kedua pasangan suami istri lanjut usia tersebut untuk meraih kesuksesan di masa lanjut, meskipun ada beberapa hal yang tidak sepenuhnya dapat mereka lakukan untuk mengusahakan kesuksesan tersebut.

Sukses adalah harapan setiap orang. Tidak mengenal umur ataupun pekerjaan, setiap orang tentunya ingin meraih kesuksesan. Sukses dapat diartikan sebagai tujuan akhir bagi banyak orang yang menjalani suatu aktivitas karena semua hal yang dilakukan harus mengarah pada satu tujuan yaitu kesuksesan. Seseorang yang memiliki kecenderungan untuk meraih sukses yang kuat dibanding dengan menghindari kegagalan.

Sukses di masa lanjut merupakan salah satu impian yang ingin diraih setiap orang. Sukses di masa lanjut dapat dikatakan sebagai suatu keberuntungan karena tidak semua orang dapat berusia panjang hingga masa lanjut. Begitupun dengan pasangan suami istri lanjut usia. Untuk meraih kesuksesan di masa lanjut bersama dengan pasangan pun adalah suatu hal yang dapat dikatakan menguntungkan karena tidak semua pasangan suami istri dapat bertahan menghadapi setiap masalah yang terjadi di dalam keluarga, khususnya keluarga yang hanya terdiri dari suami istri yang berusia lanjut karena untuk mencapai kesuksesan hingga usia lanjut bukanlah perkara yang mudah untuk dijalani. Banyak liku-liku yang harus dihadapi (S1: 527-539 W1).

Untuk meraih sukses di masa lanjut atau sering disebut dengan istilah successful aging, diperlukan banyak usaha bahkan pasangan suami istri lanjut usia yang menginginkan sukses di masa lanjut pun harus tahan banting dengan setiap masalah yang dihadapinya. Tidak jarang 
lanjut usia dipandang sebelah mata akan tetapi hal itu bukanlah penghambat untuk lanjut usia dapat bekerja untuk mencapai sukses di masa lanjut. Apapun pekerjaan yang digeluti, walalupun hanya dibayar sedikit tetapi harus ditelateni, harus sabar, dan tidak mudah bosan (S1: 188-192 W1). Selain itu juga melibatkan Alloh dalam setiap melakukan pekerjaan, jika Alloh menghendaki untuk sukses maka sukses pun akan diraih (S2: 237-242 W2).

Supaya bisa sukses bersama, seharusnya pasangan suami istri lanjut usia mengerjakan pekerjaan yang telah menjadi tujuannya, ditekuni, disyukuri, maka hal itu akan memunculkan perasaan untuk dapat berhasil (S2: 260-267 W2). Begitupun seseorang harus dapat membagi waktu untuk melaksanakan apa yang telah dikerjakannya (S2: 295-296 W2).

Dengan demikian, pasangan suami istri lanjut usia untuk meraih sukses di masa lanjut seharusnya dapat menjalani apa yang dihadapinya, dengan ditekuni, tidak lupa bersyukur, dapat membagi waktu, serta bekerja semampunya dan sekuat fisiknya mengingat keadaan lanjut usia sudah banyak fungsi di dalam tubuhnya yang mengalami penurunan.

Peneliti menyimpulkan bahwa makna sukses menurut kedua subjek pasangan suami istri lanjut usia diartikan dengan keberhasilan finansial, keberhasilan mengasuh anak, dan mempunyai keluarga yang rukun. Hal tersebut karena adanya faktorfaktor yang mempengaruhi pasangan suami istri lanjut usia untuk memaknai sukses yaitu merasa masih sehat sehingga masih kuat beraktivitas bahkan hubungan baik dengan lingkungan pun masih terjalin. Saat mengalami suatu permasalahan, pasangan suami istri lanjut usia mampu menghadapinya bersama serta mampu menyelesaikan masalah bersama. Hal tersebut karena kedua pasangan suami istri lanjut usia dalam penelitian ini mempunyai keyakinan bahwa dalam menjalani hidup ada campur tangan Tuhan. Secara keseluruhan, usaha pasangan suami istri lanjut usia yang sukses terkait dengan menjaga fungsi yang masih baik di dalam diri, kesejahteraan psikologis, menggunakan waktu sebaik mungkin untuk melakukan hal bermakna, dan keinginan untuk tetap memiliki motivasi dan mengendalikan lingkungan serta kemampuan mengatur mental, emosi, dan motivasi.

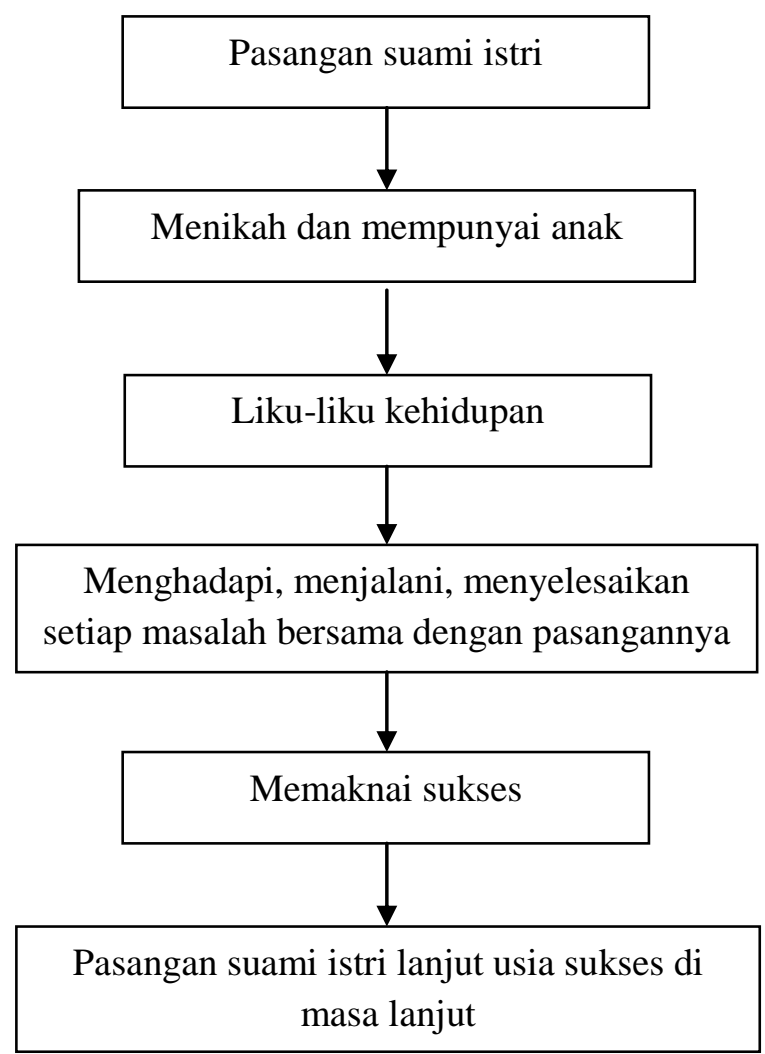

Gambar 1. Dinamika psikologis.

\section{Daftar Pustaka}

Ali, Z. (2009). Pengantar Keperawatan Keluarga. Jakarta: EGC.

Alwisol. (2004). Psikologi Kepribadian.

Malang: Universitas Muhammadiyah. Baltes, PB., dan Baltes, MM. (1990). Successful Aging: Perspectives from the Behavioral Sciences. New York: Cambridge University Press.

$\begin{array}{crr}\text { Budiarti, R. } & \text { (2010). } & \text { Faktor-faktor } \\ \text { Successful } & \text { Aging. } & \text { Skripsi. } \\ \text { Malang:UMM. } & & \end{array}$


Ekowati, CR. (2008). Penyesuaian Diri terhadap Hilangnya Pasangan Hidup pada Lansia. Skripsi. Yogyakarta: Universitas Sanata Dharma.

Hamidah dan Wrastari, AT. (2012). Studi Eksplorasi Successful Aging melalui Dukungan Sosial bagi Lansia di Indonesia dan Malaysia. Jurnal INSAN. Volume 14 Nomor 02 Halaman 108-119.

Hurlock, EB. (1999). Psikologi Perkembangan: Suatu Pendekatan Sepanjang Rentang Kehidupan Edisi Kelima. Jakarta: Erlangga.

Maryam, R. Siti, dkk. (2008). Mengenal Usia Lanjut dan Perawatannya. Jakarta: Salemba Humanika.

Moleong, LJ. (2010). Metodologi Penelitan Kualitatif. Bandung: Remaja Rosdakarya Offset.

Papalia, DE. (2004). Adult Development and Aging. New York: Mc Graw Hill Book.

Papalia, DE., Olds, SW., dan Feldman, RD. (2009). Human Development Edisi 10 Jilid 2. Jakarta: Salemba Humanika.

Rowe, JW., and Kahn, RL. (1997). Successful Aging. The Gerontologist, 37(4), 433-440.

Setiabudhi, T. dan Hardywinoto. (1999). Panduan Gerontologi Tinjuan dari Berbagai Aspek. Jakarta: Gramedia
Pustaka Utama.

Setiyartomo, PW. (2004). Successful Aging Ditinjau dari Kebermaknaan Hidup dan Orientasi Religius Pada Lanjut Usia. Tesis (Tidak diterbitkan). Yogyakarta: Fakultas Psikologi UGM.

Suardiman, SP. (2011). Psikologi Usia Lanjut. Yogyakarta: Gadjah Mada University Press.

Sugiyono. (2008). Metode Penelitian Kuantitatif, Kualitatif, dan $R \& D$. Bandung: Alfabeta.

Supratiknya, A. (1993). Psikologi Kepribadian. Yogyakarta: Kanisius. Weiner. (2003). Handbook of Psychology. New Jersey: John Willey and sons. http://www.megapolitan.kompas.com/read/ 2014/02/07/2219240/Harapan.Hidup. Warga.Yogyakarta.Paling.Tinggi.SeIndonesia diunggah pada tanggal 18 Januari 2015 pukul 20:19 WIB http://www.mizan.online.co.id/selisik/portal http://www.studibudaya.wordpress.com/20 10/02/05/menarasikan-lansia/ diunggah pada tanggal 18 September 2014 pukul 05:26 WIB 